\title{
$\boldsymbol{\beta}$-Cell cytoplasmic $\mathrm{Ca}^{2+}$ balance as a determinant for glucose-stimulated insulin release
}

\author{
B. Hellman \\ Department of Medical Cell Biology, Biomedicum, University of Uppsala, Sweden
}

\begin{abstract}
Summary. The introduction of new techniques and the access to clonal lines of insulin-secreting cells have enabled re-evaluation of glucose effects on $\mathrm{Ca}^{2+}$ movements in pancreatic $\beta$ cells. It became evident that glucose, in addition to stimulating the entry of $\mathrm{Ca}^{2+}$, also promotes active sequestration of the ion in intracellular stores and its extrusion from the $\beta$ cells. The balance between these processes will determine the activity of $\mathrm{Ca}^{2+}$ in the cytoplasm and consequently the rate of insulin release. With the demonstration that glucose can not only increase but also lower cytoplasmic $\mathrm{Ca}^{2+}$, it follows that exposure to the sugar under certain conditions results in a paradoxical inhibition of insulin release. In diabetic patients this
\end{abstract}

may be manifest as prompt reduction of circulating concentrations of insulin and C-peptide after an intravenous injection of glucose. The concept of the dual action of glucose might aid in explaining a number of poorly understood phenomena, such as the induction of rhythmic oscillations of the membrane potential of $\beta$ cells and the fact that their secretory response is improved by prolonged exposure to glucose and after priming with the sugar.

Key words: Glucose, cytoplasmic $\mathrm{Ca}^{2+}$ balance, $\beta$ cells, insulin release, depolarization, intracellular $\mathrm{Ca}^{2+}$ sequestration, diabetes.
Oskar Minkowski provided the first definite proof of a relationship between the pancreatic gland and diabetes. When receiving the Minkowski award 1969, I felt that no topic would be more appropriate for the prize lecture than the pancreatic islets. The last part of this lecture was devoted to the presentation of in vitro techniques for exploring the mechanisms for glucose regulation of insulin secretion, employing $\beta$ cell-rich pancreatic islets isolated from ob/ob-mice [1]. On this occasion, interest was focused on how the $\beta$ cells recognized glucose as a secretory stimulus. However, after the chance observation that metabolism of the sugar might be linked to ion permeability of the plasma membrane by changes in thiol/disulphide balance in a regulatory membrane protein [2], most of the subsequent research has been concerned with how glucose affects the $\beta$ cell's handling of $\mathrm{Ca}^{2+}$.

At the meeting of Minkowski prize winners in Capri in 1976 evidence was provided that, in addition to the stimulatory cytoplasmic pool of $\mathrm{Ca}^{2+}$, there also exists inhibitory calcium in the plasma membrane [3]. Since then, the introduction of new techniques and the access to clonal lines of insulin-secreting cells have enabled considerable expansion of our knowledge of $\mathrm{Ca}^{2+}$ movement in the pancreatic $\beta$ cell, culminating in the discovery that glucose has dual actions on cytoplasmic $\mathrm{Ca}^{2+}$ activity. In addition to presenting evidence for glucose initiation of $\mathrm{Ca}^{2+}$ movement with opposing ef- fects on insulin release, it will be shown how the concept of cytoplasmic $\mathrm{Ca}^{2+}$ balance could aid in explaining the rhythmic oscillations of membrane potential and other phenomena resulting from exposure of pancreatic $\beta$ cells to glucose.

\section{Influx of $\mathrm{Ca}^{2+}$}

After the original observations that glucose promotes the retention of ${ }^{45} \mathrm{Ca}$ in islets from rats [4] and $o b / o b$ mice [5], the $\mathrm{La}^{3+}$ wash technique made it possible to demonstrate that the radioactivity incorporated in response to glucose is located intracellularly [6]. The observation of a substantial islet uptake of ${ }^{45} \mathrm{Ca}$, non-displaceable by $\mathrm{La}^{3+}$, does not necessarily imply that glucose also increases intracellular calcium content. As a matter of fact, we have reason to believe that a major effect of glucose is to stimulate intracellular $\mathrm{Ca}^{2+}-\mathrm{Ca}^{2+}$ exchange. Both analysis of islets from rats using a fluorometric technique [7] and of islets from $o b / o b$-mice employing electrothermal atomic absorption spectroscopy [8] failed to demonstrate a glucose-induced increase of the total amounts of calcium. Neither was it possible to confirm reports [9] about pronounced acute glucose effects on the ${ }^{45} \mathrm{Ca}$ content of islets loaded to isotopic equilibrium [10]. However, even if most of the glucosestimulated long-term uptake of ${ }^{45} \mathrm{Ca}$ can be explained 


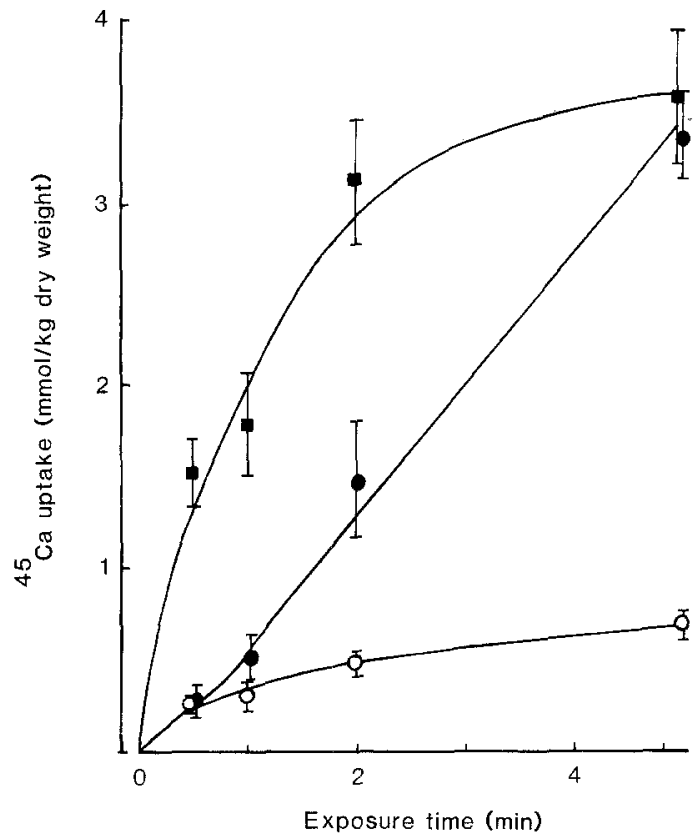

Fig. 1. Effects of glucose and excessive $\mathrm{K}^{+}$on the intracellular uptake of ${ }^{45} \mathrm{Ca}$ into pancreatic $\beta$ cells. Aggregates of cells were prepared from $\beta$-cell-rich pancreatic islets of $o b / o b$-mice and incubated for different periods of time with ${ }^{45} \mathrm{Ca}(1.28 \mathrm{mmol} / 1)$ in a Hepes-buffered medium without additives $(O)$ or supplemented with glucose $(20 \mathrm{mmol} / 1 ;-)$ or $\mathrm{KCl}(25 \mathrm{mmol} / 1 ; \mathbf{\square})$. After exposure to ${ }^{45} \mathrm{Ca}$, the cell aggregates were centrifuged through oil into a cold medium containing $\mathrm{La}^{3+}(1 \mathrm{mmol} / 1)$. Mean values $\pm S E M$ for four to five experiments

in terms of increased turnover of intracellular calcium pools, there is no longer any doubt that exposure to the sugar can also result in an increased net uptake of $\mathrm{Ca}^{2+}$ into the $\beta$ cells. In $o b / o b$-mouse islets, maintained at isotopic equilibrium, a modest (14\%) increase in the amounts of $\mathrm{La}^{3+}$-non-displaceable ${ }^{45} \mathrm{Ca}$ was observed $30 \mathrm{~min}$ after raising the glucose concentration from 5.5 to $20 \mathrm{mmol} / 1$ [10]. Moreover, it has been possible to demonstrate a glucose-stimulated net uptake of $\mathrm{Ca}^{2+}$ both in $o b / o b$-mouse islets [11] and in insulin-secreting clonal RINm5F cells [12] by monitoring alterations of the $\mathrm{Ca}^{2+}$ concentration in a suspension medium containing $\mu \mathrm{mol} / 1$ concentrations of the cation. The glucose-promoted intracellular net uptake of $\mathrm{Ca}^{2+}$ is not necessarily due to increased entry of the ion, but may also reflect a reduced outward transport. One way to discriminate between these alternatives is to measure the unidirectional influx of ${ }^{45} \mathrm{Ca}$ in short-term experiments. Several authors have performed this analysis by incubating the islets with ${ }^{45} \mathrm{Ca}$ in the presence of extracellular space markers [5, 13-15]. In an attempt to reduce the problems related to the diffusion of ${ }^{45} \mathrm{Ca}$ into the extracellular islet space and its surface binding, the technique was recently modified to allow the measurement of uptake of the isotope by suspended $\beta$ cells subsequently washed with $\mathrm{La}^{3+}$ (N. Wesslén and B. Hellman: unpublished data). Figure 1 presents results obtained with this approach. It is evident that glucose is a potent stimulator of the entry of $\mathrm{Ca}^{2+}$ into the $\beta$ cells, although the effect is delayed in comparison with that obtained after depolarization with $\mathrm{K}^{+}$.

\section{Efflux of $\mathrm{Ca}^{2+}$}

The extrusion of $\mathrm{Ca}^{2+}$ from pancreatic $\beta$ cells is mediated both by $\mathrm{Na}^{+}-\mathrm{Ca}^{2+}$ exchange diffusion [16-18] and a calmodulin-activated transport system based on a highaffinity ATPase [19]. The exploration of the $\mathrm{Ca}^{2+}$ efflux mechanism has been considerably aided by measuring the washout of radioactivity from islets loaded with ${ }^{45} \mathrm{Ca}$. Using this approach, glucose has been found to have both stimulatory and inhibitory effects on ${ }^{45} \mathrm{Ca}$ efflux (Fig. 2). The dose-response relationship for the stimulatory component mimics that of insulin release in being sigmoidal with a half-maximal response at $7-9 \mathrm{mmol} / \mathrm{l}[20,21]$. The enhanced ${ }^{45} \mathrm{Ca}$ efflux is also similar to insulin release in being associated with depolarization of the $\beta$ cells and requiring the presence of extracellular $\mathrm{Ca}^{2+}$. However, loss of calcium with the secretory granules during exocytosis can only contribute to a minor extent to the observed increase of ${ }^{45} \mathrm{Ca}$ efflux [22]. Neither does the stimulated ${ }^{45} \mathrm{Ca}$ efflux reflect a specific action of glucose in mobilizing intracellular calcium stores. Other depolarizing agents promoting the entry of $\mathrm{Ca}^{2+}$ initiate an even greater stimulation of ${ }^{45} \mathrm{Ca}$ efflux. We are therefore left with the alternative that the stimulatory component of ${ }^{45} \mathrm{Ca}$ efflux is essentially due to displacement of ${ }^{45} \mathrm{Ca}$ from intracellular binding sites following increased entry of non-radioactive $\mathrm{Ca}^{2+}[20,21,23]$. This explanation is in accordance with data, already alluded to, indicating that a major effect of glucose is to increase the turnover of intracellular calcium. Evidently glucose promotion of the intracellular ${ }^{40} \mathrm{Ca}-{ }^{45} \mathrm{Ca}$ exchange is sufficient to overcome the competitive inhibition of the outward transport of ${ }^{45} \mathrm{Ca}$ exerted by the entering ${ }^{40} \mathrm{Ca}$. Isolated pancreatic islets are not unique in responding with a stimulated ${ }^{45} \mathrm{Ca}$ efflux, when exposed to agents which increase the entry of non-radioactive $\mathrm{Ca}^{2+}$. Similar effects have been observed during perifusion studies with the posterior pituitary and adrenal medulla [24].

In accordance with the idea that stimulation of ${ }^{45} \mathrm{Ca}$ efflux results from increased entry of $\mathrm{Ca}^{2+}$, a lowering of the extracellular concentration of $\mathrm{Ca}^{2+}$ unmasked the inhibitory component of glucose action (Fig. 2). When the extracellular concentration of $\mathrm{Ca}^{2+}$ was $<0.1 \mu \mathrm{mol} / 1$, only inhibition was observed. The inhibitory component not only precedes the stimulatory phase but also disappears more rapidly on omission of glucose. Thus, at moderately reduced concentrations of $\mathrm{Ca}^{2+}$, the result is a substantial "off-induced" increase of ${ }^{45} \mathrm{Ca}$ efflux (Fig. 2B). Glucose has been found to inhibit the efflux of ${ }^{45} \mathrm{Ca}$ during perifusion with a $\mathrm{Ca}^{2+}$-deficient medium also when the islets are loaded to isotopic equilibrium. The observed inhibition cannot 


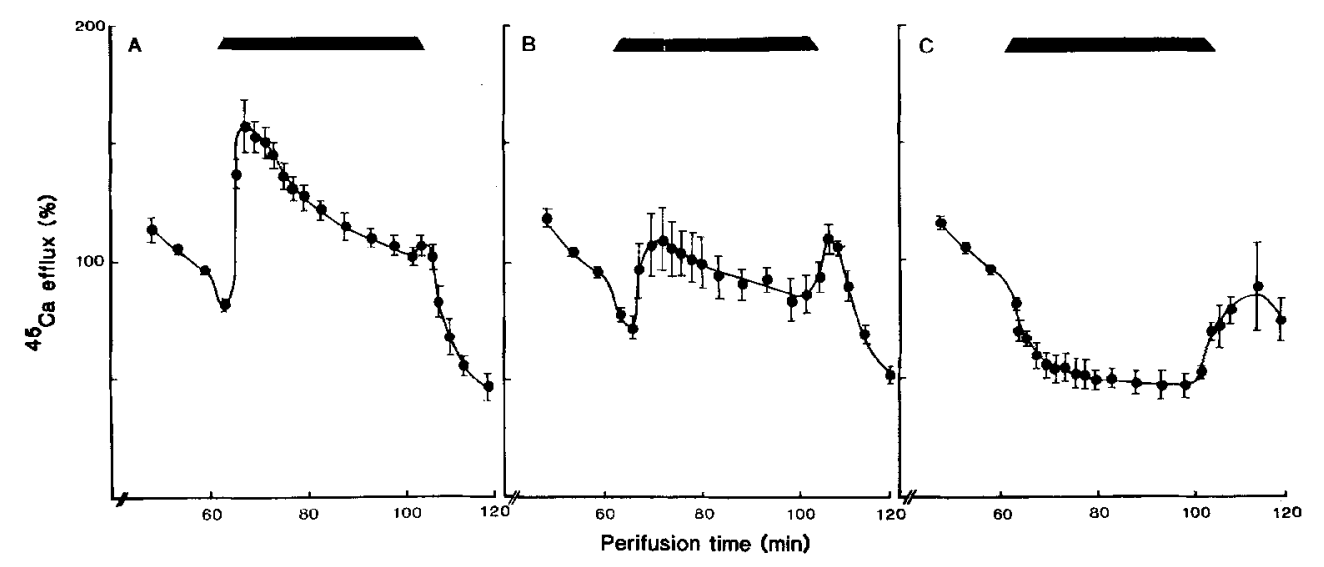

Fig. 2. Effects of glucose on ${ }^{45} \mathrm{Ca}$ efflux from $a b / o b$-mouse islets perifused with different concentrations of $\mathrm{Ca}^{2+}$. The islets were loaded with ${ }^{45} \mathrm{Ca}$ in the presence of glucose $(20 \mathrm{mmol} / \mathrm{l})$ and perifused with media containing (A) $1.2 \mathrm{mmol} / 1$, (B) $0.5 \mathrm{mmol} / 1$ or (C) $<0.1 \mu \mathrm{mol} / 1 \mathrm{Ca}^{2+}$. The lowest concentration of $\mathrm{Ca}^{2+}$ was obtained by including EGTA $(0.5 \mathrm{mmol} / 1)$ in the medium. Glucose $(20 \mathrm{mmol} / \mathrm{l})$ was introduced into the perifusion medium during the period indicated by the horizontal bar. The data are given as a percentage of the average ${ }^{45} \mathrm{Ca}$ efflux during the 10-min period preceding the introduction of glucose. Mean values $\pm S E M$ for four experiments consequently be explained by preferential mobilization of calcium stores with low specific radioactivity.

Although it is generally agreed that inhibition of ${ }^{45} \mathrm{Ca}$ efflux reflects a true decrease in the rate of $\mathrm{Ca}^{2+}$ efflux, divergent opinions have been expressed about the mechanisms involved. Apart from the original concept that glucose interferes with the active extrusion of $\mathrm{Ca}^{2+}$ from the $\beta$ cells $[15,20]$, the impaired efflux may result from trapping of the cation in cellular organelles [22]. It is essential for the understanding of glucose regulation of insulin release to discriminate between these alternatives, because of their opposite effects on the cytoplasmic concentration of $\mathrm{Ca}^{2+}$. Although islets have been reported to contain $\mathrm{Ca}^{2+}$-activated ATPase activity subject to glucose inhibition [25], the relevance of this observation for the outward transport of $\mathrm{Ca}^{2+}$ remains to be proven. We have no reason for believing that glucose inhibits $\mathrm{Ca}^{2+}$ efflux by increasing $\mathrm{Na}^{+}$activity in the pancreatic $\beta$ cells. Instead, it has been postulated that glucose inhibition of the $\mathrm{Ca}^{2+}$ efflux reflects an increased production of $\mathrm{H}^{+}$, competing with $\mathrm{Ca}^{2+}$ for exit by $\mathrm{Na}^{+}-\mathrm{Ca}^{2+}$ counter transport $[20,26,27]$. Observations in our laboratory led us to doubt that glucose interferes directly with the system for active extrusion of $\mathrm{Ca}^{2+}$. It is, for example, difficult to reconcile such an effect with the finding that inhibition of the ${ }^{45} \mathrm{Ca}$ efflux obtained in the presence of a low concentration of glucose $(4 \mathrm{mmol} / \mathrm{l})$ remains relatively unaffected by alterations of the magnitude and even direction of the $\mathrm{Ca}^{2+}$ gradient across the plasma membrane [28]. Moreover, glucose was found to be equally effective in inhibiting ${ }^{45} \mathrm{Ca}$ efflux in the absence of $\mathrm{Na}^{+}$, when the loss of intracellular $\mathrm{K}^{+}$was prevented by replacing $\mathrm{Na}^{+}$by $\mathrm{K}^{+}$ [29].

In addition to disproving the arguments for a direct inhibitory action of glucose on the outward transport of $\mathrm{Ca}^{2+}$, we have reasons for believing that this process instead will be stimulated following glucose-mediated entry of $\mathrm{Ca}^{2+}$. So far, it has not been possible to measure the unidirectional efflux component during stimulated influx of the ion. However, when taking into account that the sugar considerably enhances the entry of $\mathrm{Ca}^{2+}$ (Fig. 1) without much increasing the intracellular content of the element, it can be anticipated that the efflux of $\mathrm{Ca}^{2+}$ is raised. Indeed, it is likely that the rate of the outward transport for $\mathrm{Ca}^{2+}$ represents a complex function of cytoplasmic $\mathrm{Ca}^{2+}$ activity, as has been postulated for other cells [30].

\section{Sequestration of $\mathrm{Ca}^{2+}$ into intracellular stores}

If glucose-induced suppression of $\mathrm{Ca}^{2+}$ efflux reflects reduction of the cytoplasmic concentration after organelle uptake, it should be possible to demonstrate $\mathrm{a} \mathrm{Ca}^{2+}$ incorporation into the organelles different from that following depolarization. Experiments with labelling of the organelles in situ in the $\beta$-cell-rich pancreatic islets from $o b / o b$-mice indicated that mitochondria account for a considerable part of the ${ }^{45} \mathrm{Ca}$ taken up in response to glucose $[8,31,32]$. In the intact cells the mitochondrial net uptake of ${ }^{45} \mathrm{Ca}$ was activated even at $4 \mathrm{mmol} / 1$ glucose, a concentration insufficient for opening the voltage-dependent $\mathrm{Ca}^{2}$ channels in the plasma membrane. Moreover, the effect of glucose in retaining ${ }^{45} \mathrm{Ca}$ in the mitochondria could not be mimicked by introducing depolarizing concentrations of $\mathrm{K}^{+}$in a medium deficient in $\mathrm{Ca}^{2+}$. Since procedures for raising intracellular $\mathrm{Na}^{+}$activity have been found to be effective for mobilizing the ${ }^{45} \mathrm{Ca}$ incorporated in response to glucose $[21,33]$, it is pertinent to note that the concentration of $\mathrm{Na}^{+}$is an important denominator for the net accumulation of $\mathrm{Ca}^{2+}$ in mitochondria isolated both from normal islets [34] and a rat insulinoma [35, 36]. The $\beta$-cell mitochondria can be expected to be particularly active in buffering $\mathrm{Ca}^{2+}$ under conditions of raised cytoplasmic concentrations of this ion. The set point for $\mathrm{Ca}^{2+}$ buffering by isolated insulinoma mitochondria has been estimated as $0.9 \mu \mathrm{mol} / 1$ [35], a concentration five to ninefold that of the cytoplasm in the unstimulated $\beta$ cell.

Glucose, but not excessive $\mathrm{K}^{+}$, promoted the net uptake of $\mathrm{Ca}^{2+}$ into insulin-producing cells, when the 


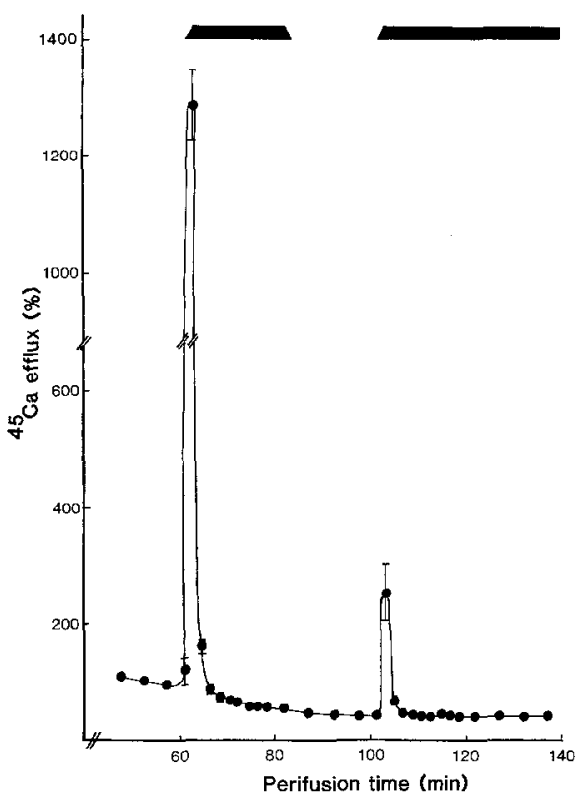

Fig. 3. Effects of carbamylcholine on ${ }^{45} \mathrm{Ca}$ efflux during perifusion with glucose-containing medium deficient in $\mathrm{Ca}^{2+}$. The islets were loaded with ${ }^{45} \mathrm{Ca}$ in the presence of glucose $(20 \mathrm{mmol} / 1)$ and perifused with a $\mathrm{Ca}^{2+}$-deficient medium supplemented with EGTA $(0.5 \mathrm{mmol} /$ 1) and glucose $(20 \mathrm{mmol} / \mathrm{l})$. Carbamylcholine $(100 \mu \mathrm{mol} / \mathrm{l})$ was introduced during the periods indicated by the horizontal bars. The data are given as percentage of the average ${ }^{45} \mathrm{Ca}$ efflux during the 10 -min period preceding the first introduction of carbamylcholine. Mean values \pm SEM for four experiments are shown

ion was present in concentrations of $10-20 \mu \mathrm{mol} / 1[11$, 12]. This observation has encouraged the search for non-mitochondrial uptake of $\mathrm{Ca}^{2+}$ stimulated by glucose. During perifusion of islets from $o b / o b$-mice with a $\mathrm{Ca}^{2+}$-deficient medium, muscarinic receptor stimulation with carbamylcholine resulted in an immediate mobilization of ${ }^{45} \mathrm{Ca}$, provided that the islets had been exposed to glucose (B.Hellman and E. Gylfe, unpublished data). This might indicate high affinity accumulation of $\mathrm{Ca}^{2+}$ in the carbamylcholine-sensitive pool, implying that the pool was also filled during perifusion with the $\mathrm{Ca}^{2+}$-deficient medium. It was consequently possible to induce a second peak of stimulated ${ }^{45} \mathrm{Ca}$ efflux, when carbamylcholine was re-introduced into the perifusion medium supplemented with glucose (Fig. 3). Muscarinic stimulation of the polyphosphoinositide breakdown may initiate a prompt mobilization of a separate pool of calcium in the pancreatic $\beta$ cells by a number of mechanisms. The rapid response is, for example, compatible with both release of calcium bound to the inner face of the plasma membrane and mobilization of calcium from the endoplasmic reticulum mediated by inositol 1,4,5-triphosphate. In support for participation of the endoplasmic reticulum, the carbamylcholine ef-

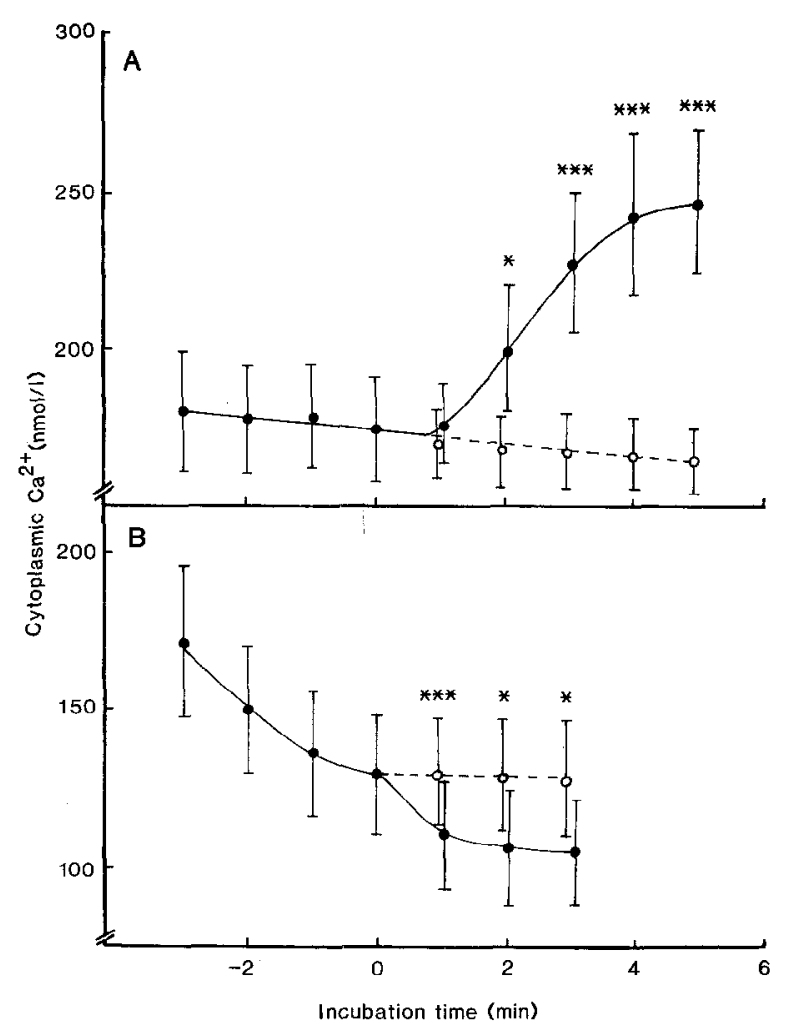

Fig. $4 \mathrm{~A}$ and $\mathrm{B}$. Effects of glucose on the cytoplasmic $\mathrm{Ca}^{2+}$ activity in suspended $\beta$ cells. Isolated cells were prepared from $\beta$-cell-rich pancreatic islets of $o b / o b$-mice and loaded with the fluorescent indicator quin-2. At zero time glucose $(20 \mathrm{mmol} / \mathrm{l})$ was added to a Hepes-buffered medium containing A 1.20 or $\mathbf{B} 0.20 \mathrm{mmol} / 1 \mathrm{Ca}^{2+}$. Open symbols and dotted lines indicate the $\mathrm{Ca}^{2+}$ activities expected without modifications of the media. Mean values \pm SEM for 11 (A) and four (B) experiments respectively. Statistically significant differences obtained with the modifications of the media are indicated by * $p<0.05$ and ${ }^{* * *} p<0.001$. Reproduced from Rorsman et al. [39]

fect was found to depend on uptake of $\mathrm{Ca}^{2+}$ promoted by $\mathrm{K}^{+}$but not by $\mathrm{Na}^{+}$.

\section{Cytoplasmic $\mathrm{Ca}^{2+}$ activity}

With the introduction of the fluorescence indicator quin-2, it has been possible to measure directly the cytoplasmic $\mathrm{Ca}^{2+}$ activity associated with alterations of insulin release. Basal $\mathrm{Ca}^{2+}$ activity was found to be $100-180 \mathrm{nmol} / 1$ in clonal tumour $\beta$ cells $[37,38]$ and normal $\beta$ cells from $o b / o b$-mice [39], and it increased substantially during stimulation of insulin release. The effect of glucose on normal $\beta$ cells is shown in Figure 4. It is evident that, in addition to raising cytoplasmic $\mathrm{Ca}^{2+}$, the sugar also has the ability to lower the activity of this ion. The latter effect became apparent when preventing the glucose-mediated entry of $\mathrm{Ca}^{2+}$ by either lowering the extracellular concentration of the ion or blocking the potential-dependent $\mathrm{Ca}^{2+}$ channels with D-600.

The observations described so far make it possible to summarize the principal actions of glucose on the cytoplasmic $\mathrm{Ca}^{2+}$ activity as shown in Table 1 . It is evi- 
Table 1. Principal actions of glucose on $\mathrm{Ca}^{2+}$ movement in pancreatic $\beta$ cells

\begin{tabular}{|c|c|c|c|c|}
\hline Property studied & Action of glucose & $\begin{array}{l}\text { Latency of effect } \\
\text { (s) }\end{array}$ & $\begin{array}{l}\text { Threshold concentration for } \\
\text { the effect of glucose } \\
(\mathrm{mmol} / \mathrm{l})\end{array}$ & $\begin{array}{l}\text { Alteration of } \\
\text { cytoplasmic } \mathrm{Ca}^{2+} \\
\text { activity }\end{array}$ \\
\hline Entry of $\mathrm{Ca}^{2+}$ & Stimulation & 60 & 5 & Increase \\
\hline Outward transport of $\mathrm{Ca}^{2+}$ & Stimulation & $>60$ & 5 & Decrease \\
\hline
\end{tabular}

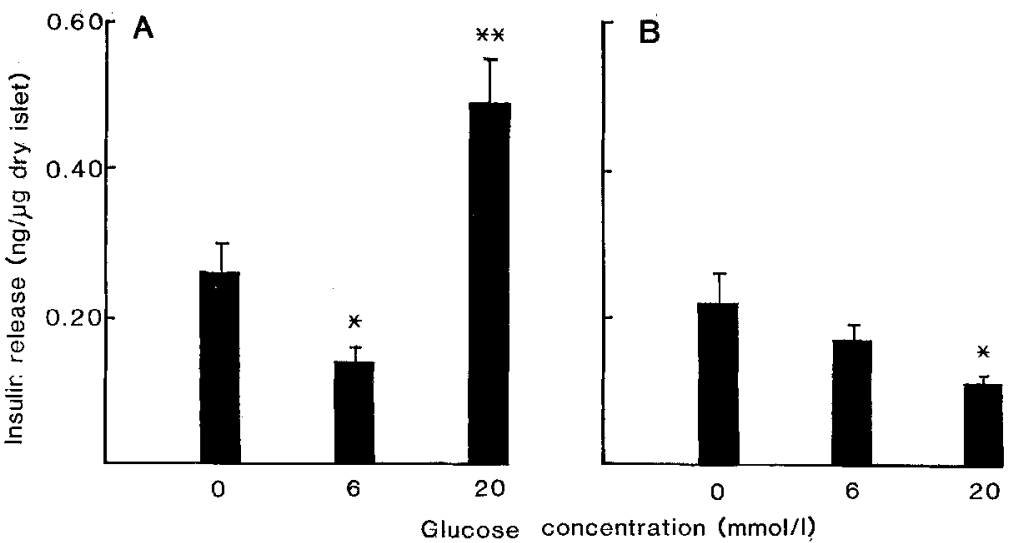

Fig. $5 \mathrm{~A}$ and B. Insulin secretory response to different concentrations of glucose in the absence $(\mathbf{A})$ or presence (B) of D-600. Islets. from $o b / o b$-mice were cultured for 3 days in $\mathrm{Ca}^{2+}$-deficient RPMI 1640 medium supplemented with glucose $(1 \mathrm{mmol} / 1), 10 \%$ serum and EGTA $(0.2 \mathrm{mmol} / \mathrm{l})$. After culture the islets were exposed to different concentrations of glucose during $60 \mathrm{~min}$ of incubation in the same type of medium containing $\mathrm{Ca}^{2+}(0.42 \mathrm{mmol} / \mathrm{l})$ and albumin $(1 \mathrm{mg} / \mathrm{ml})$. Culture and subsequent incubations of the islets were performed either in the (A) absence or $(\mathbf{B})$ presence of D-600 $(50 \mu \mathrm{mol} / 1)$. The amounts of insulin released during the incubation period are presented as mean values $\pm S E M$ for 10 experiments. Statistically significant differences from control media lacking glucose are indicated by ${ }^{*} p<0.02$ and $* * p<0.005$ dent that the available data call for a reconsideration of previous ideas that $\mathrm{Ca}^{2+}$ mobilization from intracellular stores is a factor in glucose-stimulated insulin release $[15,36]$ and that the sugar inhibits the outward transport from the pancreatic $\beta$ cells $[15,20]$. Since glucose apparently has the opposite effect, its action on cytoplasmic $\mathrm{Ca}^{2+}$ activity instead will reflect the balance between increased entry of $\mathrm{Ca}^{2+}$ and the enhanced removal of the ion from the cytoplasm by intracellular trapping and outward transport. It is important to note that glucose stimulation of these three important $\mathrm{Ca}^{2+}$ movements occurs with different latency (Table 1). As suggested from the ${ }^{45} \mathrm{Ca}$ efflux studies, and in accordance with the measurements of cytoplasmic $\mathrm{Ca}^{2+}$ activity, the intracellular sequestration of $\mathrm{Ca}^{2+}$ can be expected to be manifest earlier and at lower concentrations of glucose than those which facilitate $\mathrm{Ca}^{2+}$ influx with subsequently increased outward transport.

\section{Inhibition of insulin release}

Glucose is the major physiological stimulator of insulin release. However, it follows from its ability to lower the cytoplasmic $\mathrm{Ca}^{2+}$ activity that, under certain conditions, the sugar may also inhibit insulin release. Indeed, we have demonstrated an apparently paradoxical inhibition of insulin release in a number of experimental situations. Although it was not commented on at the time, glucose inhibition of insulin release was already observed in a $\mathrm{Ca}^{2+}$-deficient medium 10 years ago [40].

In view of the small effects of suppressing an already low cytoplasmic $\mathrm{Ca}^{2+}$ activity, it is not surprising that the inhibitory component in glucose action on insulin release has essentially escaped notice. When searching for experimental procedures to demonstrate an in- hibitory action of glucose on insulin release, it was considered important, therefore, not only to counteract the glucose-mediated entry of $\mathrm{Ca}^{2+}$ into the $\beta$ cells, but also to perform the studies under conditions in which the cytoplasmic $\mathrm{Ca}^{2+}$ activity was raised. In this way, glucose was found to inhibit the release of insulin obtained by $\mathrm{Na}^{+}$mobilization of intracellular $\mathrm{Ca}^{2+}[33]$. The inhibitory component in the glucose action on insulin release could also be clearly demonstrated after increasing the $\mathrm{Ca}^{2+}$ permeability of the $\beta$ cells by prior culture of the islets in a $\mathrm{Ca}^{2+}$-deficient medium [41]. Some of the results obtained when using this approach are shown in Figure 5 . Thus glucose $(6 \mathrm{mmol} / \mathrm{l})$ significantly inhibited insulin release, whereas a maximally depolarizing concentration of the sugar was stimulatory (Fig. $5 \mathrm{~A}$ ). The addition of D-600, a blocker of the voltage-dependent $\mathrm{Ca}^{2+}$ channels, modified the secretory response to glucose (Fig. 5B). In the latter case glucose became inhibitory even at a concentration of $20 \mathrm{mmol} / 1$. The presence of D-600 had consequently transformed a stimulatory action of glucose into inhibition, an observation reinforcing the idea that entry of $\mathrm{Ca}^{2+}$ through the voltage-dependent channels is the mechanism initiating insulin release.

\section{Functional significance of the cytoplasmic $\mathrm{Ca}^{2+}$ balance}

The discovery of opposing actions of glucose on cytoplasmic $\mathrm{Ca}^{2+}$ activity might aid the understanding of several unresolved questions related to the function of the islets in normal and diabetic organisms. Some important phenomena supposedly depending on the promotion of the intracellular sequestration of $\mathrm{Ca}^{2+}$ by glucose are given in Table 2. 
Since lowering cytoplasmic $\mathrm{Ca}^{2+}$ activity has already been suggested as a decisive factor in glucose-induced oscillations of membrane potential [42-44], it is noteworthy that in the present model the time-average effect of high concentrations of glucose is to increase cytoplasmic $\mathrm{Ca}^{2+}$ activity. However, for glucose concentrations up to $5 \mathrm{mmol} / \mathrm{l}$, it is implicit from the concept of $\mathrm{Ca}^{2+}$ balance that there will only be suppression of cytoplasmic $\mathrm{Ca}^{2+}$ activity. With the acceptance of a $\mathrm{Ca}^{2+}$-dependent $\mathrm{K}^{+}$conductance of the $\beta$ cell plasma membrane [42-44], it is easy to understand how a reduction of cytoplasmic $\mathrm{Ca}^{2+}$ resulting from intracellular buffering will initiate depolarization. Glucose concentrations above $5 \mathrm{mmol} / 1$ further increase the $\mathrm{Ca}^{+}$buffering, resulting in additional depolarization with bursts of action potentials related to the opening of voltagedependent $\mathrm{Ca}^{2+}$-channels. Lowering the cytoplasmic

Table 2. Phenomena postulated to be related to glucose promotion of intracellular sequestration of $\mathrm{Ca}^{2+}$

Depolarization induced by $\mathrm{Ca}^{2+}$-regulated $\mathrm{K}^{+}$permeability with subsequent influx of $\mathrm{Ca}^{2+}$ into pancreatic $\beta$ cells.

Appearance of a progressively increasing second phase of insulin release.

Potentiation of glucose-stimulated insulin release after priming with the sugar

Demonstration of a paradoxical glucose inhibition of insulin release in certain cases of defective $\beta$ cell function.

Glucose-induced inhibition of glucagon release from pancreatic $\alpha$ cells.

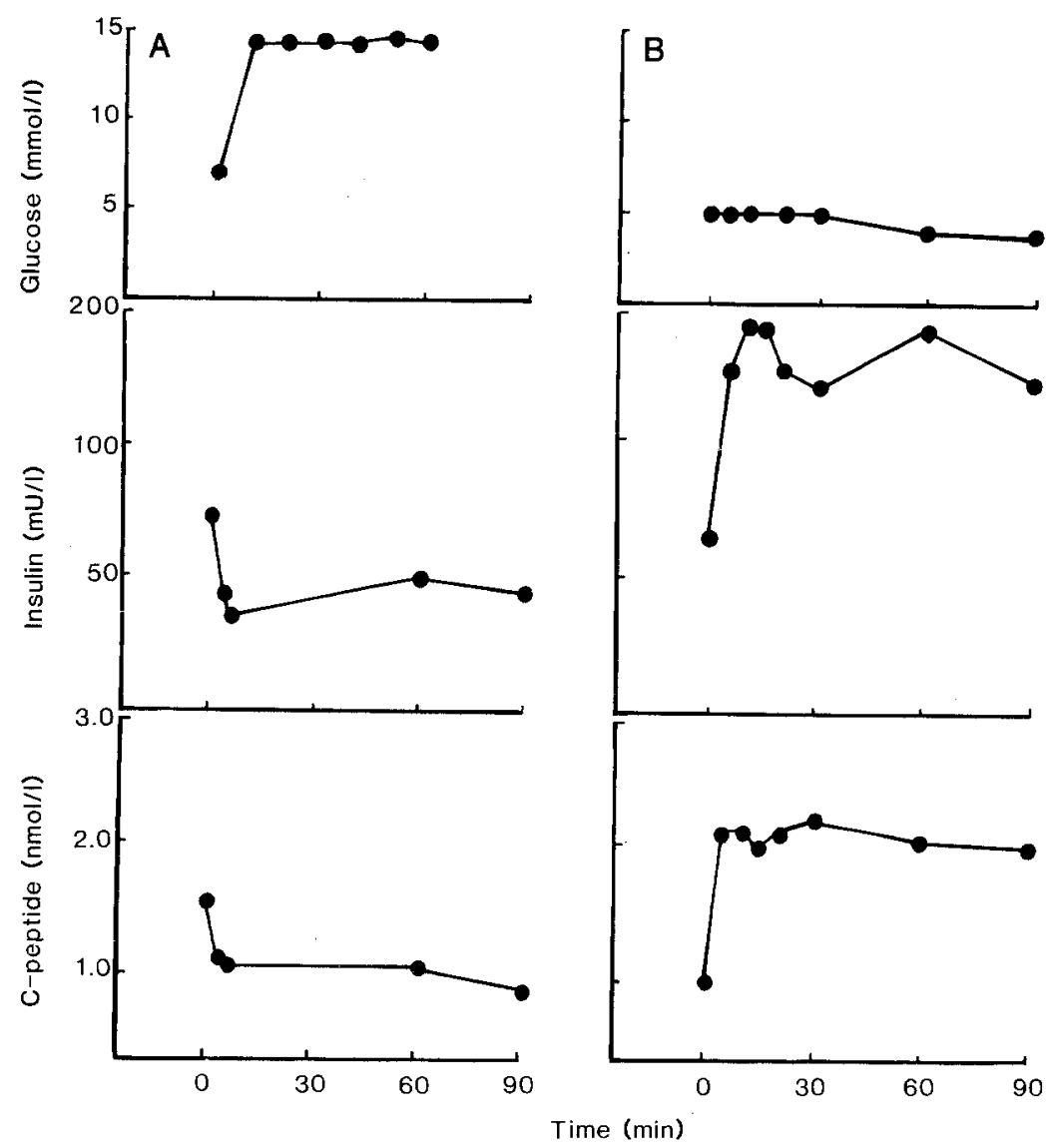

$\mathrm{Ca}^{2+}$ activity to below the resting level will consequently be a phenomenon that only occurs during a short period preceding the burst. When the glucose concentration is raised further, there is a concomitant increase of the sequestration and outward transport of $\mathrm{Ca}^{2+}$, resulting in prolongation of the bursts. A continuous burst pattern emerges at maximally stimulating concentrations of glucose, when the processes for elimination of $\mathrm{Ca}^{2+}$ from the cytoplasm balance the influx. Even if the time-average $\mathrm{Ca}^{2+}$ activity reaches a maximum in the latter situation, the highest peak activities occur at concentrations of glucose which stimulate secretion submaximally. The fact that regulation of $\mathrm{K}^{+}$conductance by $\mathrm{Ca}^{2+}$ can in itself explain the depolarizing effect of glucose by no means excludes the existence of additional mechanisms by which the sugar affects the membrane potential. Recent patch clamp studies have demonstrated that the $\beta$ cells also possess $\mathrm{K}^{+}$-selective channels, which are rapidly and reversibly blocked by cytoplasmic ATP $[45,46]$.

The intracellular buffering of $\mathrm{Ca}^{2+}$ can be expected to be less pronounced with time due to a limited capacity for sequestration. The concept of a dual action of glucose might thus explain its ability to induce an increasing second phase of insulin release and the fact that the secretory response is improved after priming with the sugar. The cyclic burst pattern of the electrical response persists during prolonged exposure to glucose, a condition supposed to be associated with saturation of the intracellular buffering system. It is likely therefore that the calmodulin-dependent plasma membrane
Fig. 6A and B. Effects of intravenous (A) glucose $(300 \mathrm{mg} / \mathrm{kg}$ body weight) and (B) tolbutamide $(1 \mathrm{mg})$ on the serum levels of glucose, insulin and C-peptide in a 14-year-old girl with mild diabetes. Reproduced from Hellman et al. [50] 
$\mathrm{Ca}^{2+}$-ATPase is deactivated more slowly than the cytoplasmic $\mathrm{Ca}^{2+}$ activity decreases. Such a mechanism should lead to reduction of cytoplasmic $\mathrm{Ca}^{2+}$ below the resting activity with subsequent initiation of depolarization. When glucose is omitted, release of $\mathrm{Ca}^{2+}$ from the sequestrating organelles prevents a rapid decrease of the cytoplasmic $\mathrm{Ca}^{2+}$ activity so that there is time for the plasma membrane $\mathrm{Ca}^{2+}$ ATPase to adapt to the new situation.

The effect of glucose in promoting intracellular sequestration can be changed to be more easily recognized under conditions, when metabolism of the sugar is unable to initiate the depolarization of $\beta$ cells. The observation of a glucose-induced inhibition of insulin release in itself suggests a defect in $\beta$ cells which may be significant for their ability to counteract diabetes. It is evident from recent studies in our laboratory (unpublished data) that the normal insulin secretory response to glucose can be altered into an inhibitory action in the presence of diazoxide, a compound supposed to counteract the depolarizing action of glucose [47]. Further evidence that impairment of $\beta$ cell function may be apparent as a paradoxical inhibition of insulin release has been obtained in studies of the perfused pancreas from rats made diabetic with alloxan (W. Grill: personal communication).

Whereas glucose-stimulated entry of $\mathrm{Ca}^{2+}$ can be regarded as specific for pancreatic $\beta$ cells, the promotion of intracellular sequestration of $\mathrm{Ca}^{2+}$ by the sugar might be a phenomenon of more general relevance. When rapidly metabolized, glucose also potentially lowers the cytoplasmic $\mathrm{Ca}^{2+}$ activity in other cells. It is still an open question whether such a mechanism accounts for the inhibitory action of glucose on the release of glucagon from pancreatic $\alpha$ cells. If this is the case, the excessive glucagon secretion in diabetes can be explained by saturation of the intracellular buffering system for calcium following prolonged exposure to raised concentrations of glucose.

\section{Cytoplasmic $\mathrm{Ca}^{2+}$ balance in human diabetes}

A paradoxical glucose inhibition of insulin release can be regarded as an indicator of defective $\beta$ cell function (Table 2). It is, therefore, not surprising that intravenous glucose infusions have been reported to result in a temporary reduction of circulating concentrations of insulin in several diabetic patients [48-50]. This largely neglected phenomenon was demonstrated recently in a patient with mild diabetes, in whom the glucose-induced depression of serum insulin was not only pronounced and long-standing, but also possible to induce after an oral load [50]. Figure 6 shows the results of intravenous injections of glucose and tolbutamide in this patient. The falling values for insulin and C-peptide are compatible with half-lives for these hormones of only 4-5 and 8-9 min, respectively. This suggests that during an initial phase glucose induces an almost complete inhibition of secretory activity in pancreatic $\beta$ cells.
In the light of the available data, it cannot be ruled out that glucose-induced suppression of circulating insulin is due to endogenous production of a non-adrenergic inhibitor of secretion, such as somatostatin. However, at least in certain cases of diabetes, it seems likely that the reduction of serum insulin reflects glucose-induced inhibition of insulin release mediated by lowering of cytoplasmic $\mathrm{Ca}^{2+}$ in analogy to the observations made in the experimental studies. Although sulphonylurea compounds are known to promote the release of somatostatin [51], tolbutamide was found to be a potent stimulator of insulin release in the patient demonstrated in Figure 6. Sulphonylureas are depolarizing agents, which promote the entry of $\mathrm{Ca}^{2+}$ by opening the voltage-dependent channels in the $\beta$ cell membrane [21,24, 52]. The patient could, therefore, be an example of a situation, where the inhibitory component in the glucose action on insulin release was unmasked due to interference with the depolarizing action of the sugar.

Acknowledgements. The development of the concept of the dual action of glucose on the cytoplasmic $\mathrm{Ca}^{2+}$ activity in the pancreatic $\beta$ cells was possible by joint efforts with several colleagues. I had the privilege to share the ideas and constructive criticism of my collaborator E. Gylfe during all stages of the work. Among the younger generation at the Department of Medical Cell Biology in Uppsala, significant contributions have been made by H.Abrahamsson, T.Andersson, P. Arkhammar, P.-O.Berggren, P. Bergsten, T. Nilsson, F. Rorsman, P. Rorsman and N. Wesslén. In exploration of the paradoxical glucose effect in lowering serum levels of insulin in diabetic patients, the clinical expertise of C. Berne, R. Hällgren and L. Wide from the University Hospital has been of utmost importance. Among my intellectual creditors I also wish to thank N. Marsden from the Department of Physiology and Medical Biophysics. Professional technical assistance has been given by C.Edström, L. Forsberg, T. Honkanen, M. Lindfors, K. Mustajärvi, C. Nimbratt, K. Rune and I. Rönnberg. $\mathrm{K}$. Linder is acknowledged for excellent secretarial aid for almost 20 years. Financial support for the studies has been given by the Swedish Medical Research Council (12x-562), the Swedish Diabetes Association, Nordic Insulin Foundation and the Wenner-Gren and Wallenberg Foundations.

\section{References}

1. Hellman B (1970) Methodological approaches to studies on the pancreatic islets. Diabetologia 6: 110-120

2. Hellman B, Idahl L-Å, Lernmark $\AA$, Sehlin J, Täljedal I-B (1974) Membrane sulphydryl groups and the pancreatic beta cell recognition of insulin secretagogues. In: Malaisse WJ, Pirart $\mathbf{J}$ (eds) Diabetes. Procedings of the 8th Congress of the International Diabetes Federation, Excerpta Medica, Amsterdam, pp 65-78

3. Hellman B (1976) Calcium and the control of insulin secretion. In: Lindenlaub E (ed) Meeting of the Minkowski prize winners. FK Schattauer Verlag, Stuttgart, pp 207-222

4. Malaisse-Lagae F, Malaisse WJ (1971) Stimulus-secretion coupling of glucose-induced insulin release. III. Uptake of ${ }^{45} \mathrm{calcium}$ by isolated islets of Langerhans. Endocrinology 88: 72-80

5. Hellman B, Sehlin J, Täljedal I-B (1971) Calcium uptake by pancreatic $\beta$ cells as measured with the aid of ${ }^{45} \mathrm{Ca}$ and mannitol $-{ }^{3} \mathrm{H}$. Am J Physiol 221: 1795-1801

6. Hellman B, Sehlin J, Täljedal I-B (1976) Effect of glucose on ${ }^{45} \mathrm{Ca}^{2+}$ uptake by pancreatic islets as studied with the lanthanum method. J Physiol (Lond) 254: 639-656

7. Wolters GHJ, Wiegman JB, Konijnendijk W (1982) The effect of glucose stimulation on ${ }^{45}$ calcium uptake of rat pancreatic islets and their total calcium content as measured by a fluorometric micromethod. Diabetologia 22: 122-127 
8. Andersson T, Berggren PO, Gylfe E, Hellman B (1982) Amounts and distribution of intracellular magnesium and calcium in pancreatic $\beta$ cells. Acta Physiol Scand 114: 235-241

9. Ribes G, Siegel E, Wollheim CB, Renold AE, Sharp GWG (1981) Rapid changes in calcium content of rat pancreatic islets in response to glucose. Diabetes 30: 52-55

10. Bergsten P, Hellman B (1984) Differentiation between short and long term effects of glucose on the intracellular calcium content of the pancreatic $\beta$ cell. Endocrinology 114: 1854-1859

11. Gylfe $\mathrm{E}$ (1982) Glucose-stimulated net uptake of $\mathrm{Ca}^{2+}$ in the pancreatic $\beta$ cell demonstrated with dual wavelength spectrophotometry. Acta Physiol Scand 114: 149-151

12. Gylfe E, Andersson T, Rorsman $P$, Abrahamsson $H$, Arkhammar P, Hellman P, Hellman B, Oie HK, Gazdar AF (1983) Depolarization-independent net uptake of calcium into clonal insulin-releasing cells. Biosci Rep 3: 927-937

13. Naber S, McDaniel ML, Lacy PE (1977) The effect of glucose on the acute uptake and efflux of calcium- 45 in isolated rat islets. Endocrinology 101: 686-693

14. Frankel BJ, Kromhout JA, Imagawa W, Landahl HD, Grodsky GM (1978) Glucose-stimulated ${ }^{45} \mathrm{Ca}$ uptake in isolated rat islets. Diabetes 27: 365-369

15. Wollheim CB, Sharp GWG (1981) Regulation of insulin release by calcium. Physiol Rev 61:914-973

16. Hellman B, Andersson T, Berggren P-O, Rorsman P (1980) Calcium and pancreatic $\beta$ cell function. II. Modification of ${ }^{45} \mathrm{Ca}$ fluxes by $\mathrm{Na}^{+}$removal. Biochem Med 24: 143-152

17. Herchuelz A, Malaisse WJ (1980) Regulation of calcium fluxes in rat pancreatic islets: dissimilar effects of glucose and of sodium ion accumulation. J Physiol (Lond) 302: 263-280

18. Siegel EG, Wollheim CB, Renold AE, Sharp GWG (1980) Evidence for involvement of $\mathrm{Na} / \mathrm{Ca}$ exchange in glucose-induced insulin release from rat pancreatic islets. J Clin Invest 66: 996-1003

19. Pershadsingh HA, McDaniel ML, Landt M, Bry CG, Lacy PE, McDonald JM (1980) $\mathrm{Ca}^{2+}$-activated ATPase and ATP-dependent calmodulin-stimulated $\mathrm{Ca}^{2+}$ transport in islet cell plasma membrane. Nature 288: 492-495

20. Herchuelz A, Malaisse WJ (1981) Calcium movements and insulin release in pancreatic islets. Diabete Metab 7:283-288

21. Hellman B, Gylfe E (1985) Calcium and the control of insulin secretion. In: Cheung WY (ed) Calcium and cell function, vol 6. Academic Press, New York, (in press)

22. Hellman B, Andersson T, Berggren P-O, Flatt P, Gylfe E, Kohnert $\mathrm{K}-\mathrm{D}(1979)$ The role of calcium in insulin secretion. In: Dumont $J$, Nunez J (eds) Hormone and cell regulation, vol 3. Elsevier/North Holland Biomedical Press, Amsterdam, pp 69-96

23. Hellman B, Gylfe E (1985) Glucose regulation of insulin release involves intracellular sequestration of calcium. In: Rubin RP, Weiss GB, Putney Jr JW (eds) Calcium in biological systems. Plenum Publishing Corp, New York, pp 93-99

24. Gylfe E, Hellman B (1982) Lack of $\mathrm{Ca}^{2+}$ ionophoretic activity of hypoglycemic sulfonylureas in excitable cells and isolated secretory granules. Mol Pharmacol 22: 715-720

25. Levin SR, Kasson BG, Driessen JF (1978) Adenosine triphosphatases of rat pancreatic islets. Comparison with those of rat kidney. J Clin Invest 62: 692-701

26. Malaisse WJ, Hutton JC, Kavazu S, Herchuelz A, Valverde I, Sener A (1979) The stimulus-secretion coupling of glucose-induced insulin release. XXXV. Links between metabolic and cationic events. Diabetologia 16: 331-334

27. Lebrun P, Malaisse WJ, Herchuelz A (1982) Effect of the absence of bicarbonate upon intracellular $\mathrm{pH}$ and calcium fluxes in pancreatic islet cells. Biochim Biophys Acta 721:357-363

28. Hellman B, Gylfe E (1984) Evidence for glucose stimulation of intracellular buffering of calcium in the pancreatic $\beta$ cell. Q J Exp Physiol 69: 867-874

29. Hellman B, Gylfe E (1984) Glucose inhibits ${ }^{45} \mathrm{Ca}$ efflux from pancreatic $\beta$ cells also in the absence of $\mathrm{Na}^{+}-\mathrm{Ca}^{2+}$ countertransport. Biochim Biophys Acta 770: 136-141

30. Rasmussen H (1981) Calcium and cAMP as synarchic messengers. John Wiley, New York, pp 1-370

31. Kohnert KD, Hahn HJ, Gylfe E, Borg H, Hellman B (1979) Cal- cium and pancreatic $\beta$ cell function. 6. Glucose and intracellular ${ }^{45} \mathrm{Ca}$ distribution. Mol Cell Endocrinol 16: 205-220

32. Andersson T (1983) Glucose-induced retention of intracellular ${ }^{45} \mathrm{Ca}$ in pancreatic islets. Am J Physiol 245: C343-C347

33. Hellman B, Honkanen T, Gylfe E (1982) Glucose inhibits insulin release induced by $\mathrm{Na}^{+}$mobilisation of intracellular calcium. FEBS Lett 148: 289-292

34. MacDonald MJ (1984) The use of calcium uptake by small amounts of mitochondria from pancreatic islets to study mitochondrial respirations. The effects of diazoxide and sodium. Biochem Int 8: 771-778

35. Prentki M, Janjic D, Wollheim CB (1983) The regulation of extramitochondrial steady state free $\mathrm{Ca}^{2+}$ concentration by rat insulinoma mitochondria. J Biol Chem 258: 7597-7602

36. Prentki M, Wollheim CB (1984) Cytosolic free $\mathrm{Ca}^{2+}$ in insulin secreting cells and its regulation by isolated organelles. Experientia 40: $1052-1060$

37. Rorsman P, Berggren P-O, Gylfe E, Hellman B (1983) Reduction of the cytosolic calcium activity in clonal insulin-releasing cells exposed to glucose. Biosci Rep 3:939-946

38. Wollheim CB, Pozzan T (1984) Correlation between cytosolic free $\mathrm{Ca}^{2+}$ and insulin release in an insulin-secreting cell line. $\mathrm{J}$ Biol Chem 259: 2262-2267

39. Rorsman P, Abrahamsson H, Gylfe E, Hellman B (1984) Dual effects of glucose on the cytosolic $\mathrm{Ca}^{2+}$ activity of mouse pancreatic $\beta$ cells. FEBS Lett 170: 196-200

40. Hellman B (1975) The significance of calcium for glucose stimulation of insulin release. Endocrinology 97: 392-398

41. Bergsten P, Hellman B (1984) Glucose inhibits insulin release when not promoting the entry of calcium into the $\beta$ cells. Biochem Biophys Res Commun 125: 875-881

42. Atwater I, Dawson CM, Ribalet B, Rojas E (1979) Potassium permeability activated by intracellular calcium ion concentration in the pancreatic $\beta$ cell. J Physiol (Lond) 288: 575-588

43. Ribalet B, Beigelman PM (1979) Cyclic variation of $\mathrm{K}^{+}$conductance in pancreatic $\beta$ cells: $\mathrm{Ca}^{2+}$ and voltage dependence. Am J Physiol 237: C137-C146

44. Cook DL (1984) Electrical pacemaker mechanisms of pancreatic islet cells. Fed Proc 43: 2368-2372

45. Cook DL, Hales CN (1984) Intracellular ATP directly blocks $\mathrm{K}^{+}$ channels in pancreatic $\beta$ cells. Nature $311: 271-273$

46. Rorsman P, Trube G (1985) Evidence that D-glucose-induced depolarization in pancreatic $\beta$ cells involves the closure of an ATP. dependent $\mathrm{K}^{+}$channel. Acta Physiol Scand (in press)

47. Henquin JC, Charles S, Nenquin M, Mathot F, Tamagawa $T$ (1982) Diazoxide and D-600 inhibition of insulin release. Distinct mechanisms explain the specificity for different stimuli. Diabetes 31: 776-783

48. Robertson RP, Brunzell JD, Hazzard WR, Lerner RL, Porte Jr D (1972) Paradoxical hypoinsulinaemia: an alpha-adrenergic-mediated response to glucose. Lancet 2: 787-789

49. Metz SA, Halter JB, Robertson RP (1979) Paradoxical inhibition of insulin secretion by glucose in human diabetes mellitus. J Clin Endocrinol Metab 48: 827-835

50. Hellman B, Hällgren R, Abrahamsson H, Bergsten P, Berne C Gylfe E, Rorsman P, Wide L (1985) The dual action of glucose on the cytosolic $\mathrm{Ca}^{2+}$ activity in pancreatic $\beta$ cells. Demonstration of an inhibitory effect of glucose on insulin release in the mouse and man. Biomed Biochim Acta 44: 63-70

51. Efendic S, Enzmann F, Nylén A, Uvnäs Wallensten K, Luft R (1979) Effect of glucose/sulfonylurea interaction on release of insulin, glucagon and somatostatin from isolated perfused rat pancreas. Proc Natl Acad Sci USA 76: 5901-5904

52. Gylfe E, Hellman B, Sehlin J, Täljedal I-B (1984) Interaction of sulfonylurea with the pancreatic $\beta$ cell. Experientia $40: 1126-1134$

\section{Dr. Bo Hellman}

Department of Medical Cell Biology

Biomedicum, Box 571

S-75123 Uppsala

Sweden 